\title{
A Learning Philosophy Assignment Positively Impacts Student Learning Outcomes
}

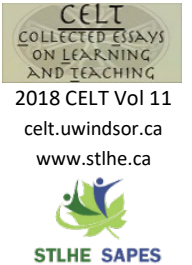

\author{
Neil Haave, Kelly Keus, \& Tonya Simpson \\ University of Alberta
}

DOI: 10.22329/celt.v11i0.4969

This study analyzed the effect of a learning philosophy assignment on students' intellectual development and mastery of first-year biology and second-year biochemistry course content. We used pre-and post-surveys to assess students' cognitive complexity, and compared students' midterm and final exam marks to assess mastery of course content. The learning philosophy assignment rescued students in the biology course from a decrease in cognitive complexity. Additionally, second-year students were rescued from performing poorly on the biochemistry final exam relative to the midterm, and also showed increases in cognitive complexity. These results suggest that a learning philosophy assignment may be an effective way of engaging students in metacognition of their learning to promote their intellectual development and mastery of course material.

Cette étude consiste en l'analyse de l'effet d'un devoir portant sur la philosophie de l'apprentissage sur le développement intellectuel des étudiants et sur leur maîtrise de la matière des cours de biologie de première année et de biochimie de deuxième année. Nous avons utilise des sondages avant et après le devoir afin d'évaluer la complexité cognitive des étudiants. Nous avons également comparé les résultats des étudiants aux examens de mi-session et de fin de session afin d'évaluer leur maîtrise de la matière du cours. Grâce au devoir sur la philosophie de l'apprentissage, les étudiants du cours de biologie n'ont pas vu leur complexité cognitive diminuer. De plus, les étudiants de deuxième année ont ainsi pu éviter d'obtenir, dans leur examen final de biochimie, des résultats inférieurs à ceux de leur examen de mi-session, tout en montrant les signes d'un accroissement de la complexité cognitive. Les résultats de l'étude suggèrent qu'un devoir sur la philosophie de l'apprentissage peut aider les étudiants à participer à un processus de métacognition de leur apprentissage, ce qui favoriserait leur développement intellectuel et leur maîtrise de la matière du cours.buy-in.

$\mathrm{M}$ any universities and colleges enable students to track the completion of their degree program. At Augustana, we provide students with a Program Planning Form that organizes their courses into the different requirements for graduation. Many of our students, however, seem to use this as the frame for viewing their education: a list of boxes to be checked. Many students do not understand the overarching coherence in their major and general education requirements. Curricular coherence is present but Augustana has not always explicitly explained this to our students. As a result, many students collect a pile of courses without assembling them into an education (Smith, 1998).

Augustana's current core curriculum is a general education that meets the breadth needs of our students and inculcates in students the particular values held by the Augustana professoriate, 
developing their communication, thinking, and research skills. In the late 2000s, our administration noticed that our graduates displayed difficulties articulating their skills to potential employers. Similarly, some instructors noticed students having difficulty applying prior learning from pre-requisite classes. Students seemed to be engaged in a learning cycle of memorize-regurgitate-purge as a result of not integrating their learning experiences into an interconnected and robust knowledge structure. Constructivist learning theory suggests that deep learning - learning that sticks - best occurs if students weave their education into their existing mental models of how the world works (Hartle, Baviskar, \& Smith, 2012). Studies from educational psychology support this view (Ambrose et al., 2010; Brown, Roediger III, \& McDaniel, 2014). To investigate how Augustana could facilitate deeper learning in our students, we conducted an e-portfolio pilot during which it was noticed that students had not been asking questions about their own learning (Haave, 2014). We noticed that our students were not metacognitively engaged in their learning processes.

Simply put, metacognition is thinking about thinking (Flavell, 1979; Girash, 2014; Millis, 2016). Flavell (1979) originally coined metacognition within a developmental context; his work assumes a progression of metacognition in children as they develop. Research attempts to further subdivide metacognition into several types of cognitive awareness have remained somewhat fluid. In current education research, metacognition is commonly divided into two categories: metacognitive knowledge and metacognitive regulation. Metacognitive knowledge encompasses the explicit awareness of our own thinking - in broadest terms, being aware that we are having a thought (Coutinho, 2007; Girash, 2014; Stanton, Neider, Gallegos, \& Clark, 2015). In educational contexts, metacognitive knowledge includes an awareness of our conceptual understanding (e.g., I learnt about the cell today or I do/do not know how to define synesthesia) and an awareness of our learning strategies and skills, including when we employ them (e.g., I have excellent writing skills or I learn best when I practice end of chapter questions). Metacognitive regulation involves controlling our thinking and can be divided into three parts: monitoring, evaluating, and planning (Coutinho, 2007; Girash, 2014; Stanton et al., 2015). Regarding learning, metacognitive regulation involves controlling our thinking to learn; therefore, we monitor our ongoing conceptual understanding and our learning strategies (both how we are learning the strategy and whether the strategy is effective over time). Additionally, we use our metacognitive knowledge and our monitoring to make appropriate plans to achieve our goals (e.g., after the midterm, I decided to start completing practice questions).

According to the American Psychological Association, successful learners engage in metacognitive thinking (Learner-Centered Principles Work Group, 1997). Metacognition is considered a skill that teachers can offer students to improve their own learning outcomes beyond discipline specific material (Girash, 2014; Hartle et al., 2012; Pintrich, 2002; Stanton et al., 2015). Developing students' metacognition has been suggested to improve students' academic achievement (Ambrose et al., 2010; Girash, 2014; Tanner, 2012) possibly by developing students' critical thinking (Magno, 2010). In a sample of first-year medical students, researchers found that metacognitive regulation increased across the school year (Hong, Vadivelu, Daniel, \& Sim, 2015). Furthermore, metacognitive regulation was moderately correlated with academic achievement. A lack of metacognition has been correlated with students' inability to assess their own knowledge and academic abilities (Bell \& Volckmann, 2011; Dunning, Johnson, Ehrlinger, \& Kruger, 2003). In a study designed to test the monitoring arm of metacognitive regulation, it was found that lowperforming students were more likely to inaccurately assess their academic performance; specifically, they overestimate (Händel \& Fritzsche, 2015). Paradoxically, these students show an awareness of their poor metacognitive ability and report low confidence levels in their own assessments. Evidence suggests that student learning outcomes may be improved by attending to metacognition through activities that use personal response systems (Brady, Seli, \& Rosenthal, 2013), in-class writing and 
discussion assignments (Mynlieff, Manogaran, St. Maurice, \& Eddinger, 2014; Zhao, Wardeska, McGuire, \& Cook, 2014), and correlates with students' mastery goals (Coutinho, 2007). One Australian study has shown that metacognitive and self-efficacy abilities are not correlated to student learning outcomes as measured by grade point average (GPA) (Zeegers, 2004).

Educators often advocate that we move beyond GPA as a measure of student success especially since GPA is not always correlated with intellectual development (Marra \& Palmer, 2004; Moore, 1989). The Perry scheme of intellectual and ethical development is a common measure in education research (Baxter Magolda, 2006; Felder \& Brent, 2004; Finster, 1989; Marra, Palmer, \& Litzinger, 2000). It posits that students' understanding of the world develops through nine positions which have been collapsed into four stages (Marra et al., 2000; Moore, 2002; Perry, 1981). Students typically enter postsecondary education with a dualistic understanding of the world in which absolute truth exists (Perry, 1998). Dualistic students think that there is a right and a wrong answer and often look to the teacher to provide the correct answer. Ironically, it is in dualism that students are most sure of their knowledge (Finster, 1989). In the next stage of the Perry scheme, multiplicity, uncertainty exists (Perry, 1998). In this second level, the possibility of a right answer exists and students may travel a continuum from believing they will find it to believing that they will never know. If the answer is unknowable, everyone's opinion is valid. It is in multiplicity that students reach their nadir of certainty of knowledge. The third stage of students' intellectual development involves contextual relativism in which context matters when determining the right answer. The learner must take a point of view and actively make meaning. Students in this penultimate stage of the Perry scheme can foresee commitment and that there is no absolute truth. In this stage, the learner is responsible for his or her own judgments. Commitment with relativism is the final stage in the Perry scheme of intellectual development and primarily involves ethics. At this final level of intellectual development, commitments are made after careful consideration of legitimate alternatives and reflect self-identity. A small minority of undergraduate students complete this final stage (Perry, 1998).

Other theories and methods to investigate students' intellectual development have been established (Baxter Magolda, 2006; Felder \& Brent, 2004) and the impact of developing students' intellectual level has been assessed by considering general education learning outcomes (critical thinking, citizenship, intercultural competence, communication) but not students' understanding of their major subject of study, although this has been proposed to improve (Pintrich, 2002). We chose the Perry scheme because it is relatively easy to assess using the Learning Environment Preferences survey as opposed to more involved interview methods (Moore, 1989). Our study considers whether the development of students' metacognitive ability through the creation of their own learning philosophy (LP) can positively impact students' course content mastery in addition to their intellectual development.

\section{Methods}

We used a concurrent nested mixed-methods approach (Warfa, 2016) to determine quantitatively if an LP assignment improves both specific and general student learning outcomes. In addition, we also analyzed the qualitative nature of the metacognition in students' written LP assignments. Our intent was to determine whether an LP assignment improved student learning of the course content (specific learning outcome) and their level of intellectual development (general learning outcome) and if so, how the LP assignment may have initiated the effect on student learning outcomes. The learning philosophy assignment asked students a series of questions (Table 1) to which the students were required to answer either each separately or incorporated into a short essay response (approximately two typewritten pages; see appendix A to review the entire assignment). This was done in two stages. Students opting to complete the LP assignment submitted a first draft before the midterm exam to which we supplied feedback after their 
Table 1

Questions included in the learning philosophy

assignment

What, how, and why did you learn?

How does learning feel and affect you?

Does the material have future relevance?

Did you receive and/or incorporate feedback?

Would you change your learning approach?

midterm exams were returned. The feedback typically consisted of asking students to be more explicit and provide deeper consideration in their responses. For example, a common feedback comment was to ask students why they thought their learning strategies were working - they were asked for what evidence they used to support their claim that their learning strategies were working. In addition, feedback sometimes included examples of how what they were learning might be relevant to their after-degree goals. Students then submitted a second draft of their LP assignment during the last week of classes before the final exam with the explicit understanding that students would be graded on their response to the midterm feedback. It was made clear to students that although there were no right or wrong answers, there were answers that were better articulated with deeper consideration of their learning.

We collected data from first-year biology (Fall 2015) and second-year biochemistry (Winter 2016) courses and compared the level of intellectual development and raw, uncurved exam marks of students who did and did not complete the learning philosophy assignment. Both courses were taught using the active learning teaching strategy of TeamBased Learning (TBL) (Michaelsen \& Sweet, 2011). Thus, this study did not assess the merits of active learning as that has already been firmly established (Freeman et al., 2014). Rather, we were interested in contributing to our understanding how active learning is best implemented (Dolan, 2015). For the first-year biology course, the LP assignment was embedded as an application (App) in one of the two sections of the course for that term and was thus a regular marked TBL App. The control section (-LP) also had marked TBL Apps, but a learning philosophy assignment was not included. In both sections, the Apps contributed 5\% toward students' final mark. For the second-year biochemistry course, students enrolled in the same single section of the course were given the option of completing the LP assignment which contributed toward $10 \%$ of their final mark. The control students who opted to not complete a LP assignment had their midterm and final exams contribute $5 \%$ greater weight (30 and $40 \%$ respectively) toward their final mark than the +LP students.

The students whose work was analyzed consented to their participation in the study. Student consent was obtained by the research assistant during the last week of exams. The instructor is never aware of which students consent. This study received approval by our university's research ethics board (Project \#56316). Student work was anonymized except in those cases in which students indicated that they wished to be identified. Students' level of intellectual development was operationalized as a cognitive complexity index (CCI) as determined by the Learning Environment Preferences (LEP) survey (Moore, 1989). See Appendix B for the survey questions. The survey prompts students to consider the significance of five different domains of their ideal learning environment (Table 2). Scoring the survey is

\section{Table 2}

The five learning domains that are assessed by the Learning Environment Preferences survey

Course content and students' view of learning Role of the instructor

Role of the student and their peers

Classroom atmosphere and activities

Role of evaluation procedures and grading 
completed by the Center for the Study of Intellectual Development, which returns a composite Cognitive Complexity Index (CCI). The study collected preand post-data (CCI and exam marks) between which the LP assignment was completed with feedback (Figure 1).

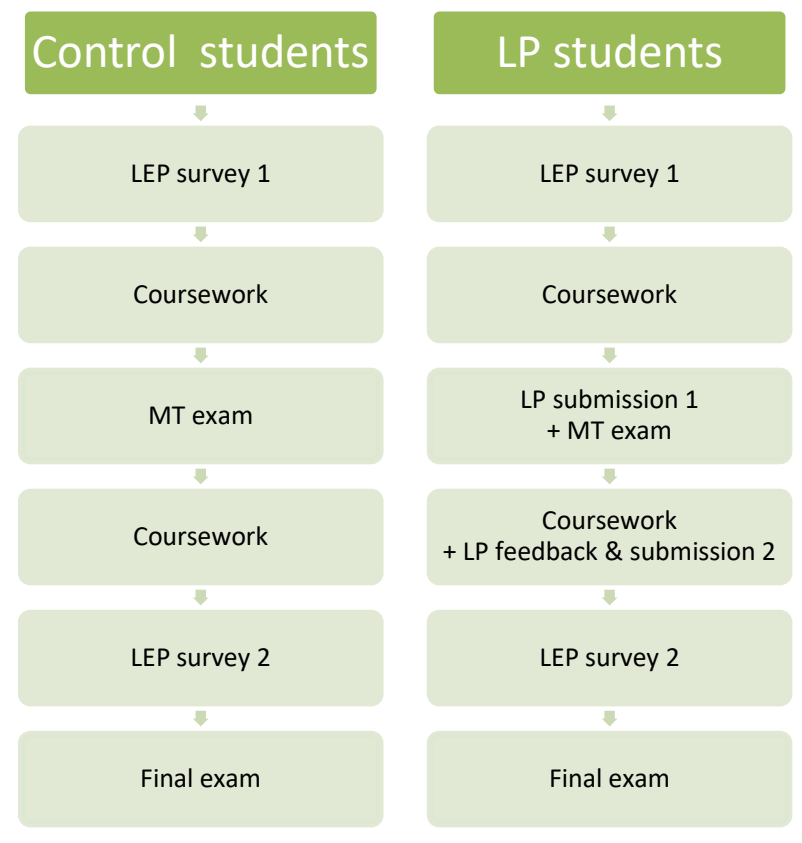

Figure 1

Sequencing of the Learning Environment Preferences (LEP) survey, coursework, and exams. The exams and LEP survey were quantitatively analyzed whereas the learning philosophy (LP) assignment was qualitatively analyzed.

The effect of the LP assignment on students' exams and LEP surveys was analyzed in a pretest/ post-test fashion using one-tailed paired t-tests. This design was chosen because we were interested in determining how individual students changed across the semester. We expected students who did not complete the LP assignment to perform more poorly on their final relative to their midterm exam and hypothesized that students who completed the LP would perform better on their final exam (Zhao et al., 2014) and would increase their cognitive complexity index. Chi-square tests checked for differences in the demographics (i.e., gender, major, program, yearlevel) between the learning philosophy $(+\mathrm{LP})$ and control (-LP) groups of students. In the first-year biology course, there was an imbalance in students enrolled in Bachelor of Arts (BA) versus Bachelor of Science (BSc) degree programs. The few BA students were therefore removed from the analysis. In the second-year biochemistry course, there were no demographic differences except for two non-BSc students; their data is included in this analysis because they were studying biology (a major or minor). As we were unable to access prior GPA, we completed an unpaired t-test that found no differences in the initial level of intellectual development or midterm exam scores between the +LP and -LP groups of the firstyear biology ( $\mathrm{n}=21$ and 29 , respectively) and secondyear biochemistry ( $\mathrm{n}=24$ and 19, respectively) students. Students were given the choice of whether they would complete the LP assignment.

Students' LPs were assessed for metacognitive content with the aid of the software program NVivo ${ }^{\mathrm{TM}}$. Primarily, our qualitative analysis was designed to ensure that our metacognitive prompts were effective. Two specific types of metacognitive knowledge were coded: awareness of conceptual understanding and awareness of learning strategies (Figure 2). It quickly became apparent that students recognized their learning strategies in two ways, explicitly and vaguely. Students who gave clear opinions on why they were using a strategy with supporting evidence were coded as explicit, while students who labelled a strategy without support and/or an opinion on efficacy were labelled as vague. Metacognitive regulation was also further subdivided, and LPs were coded for evidence of monitoring and planning. Two types of monitoring were considered: monitoring comprehension and monitoring learning strategies. Additionally, students appeared to express either abstract or concrete plans, therefore, this category was also divided. The abstract plans remained unimplemented. However, many students moved beyond simply answering the question and made specific plans and changes to their learning strategies between the midterm and final. These answers were labelled concrete. Assignments were also 
coded for evidence of the three Perry scheme positions most likely to occur in undergraduate students: dualism, multiplicity, and relativism (Finster, 1989). Because students were prompted with specific questions during the LP assignment, several patterns emerged within answers to specific questions. These are presented in the results section.

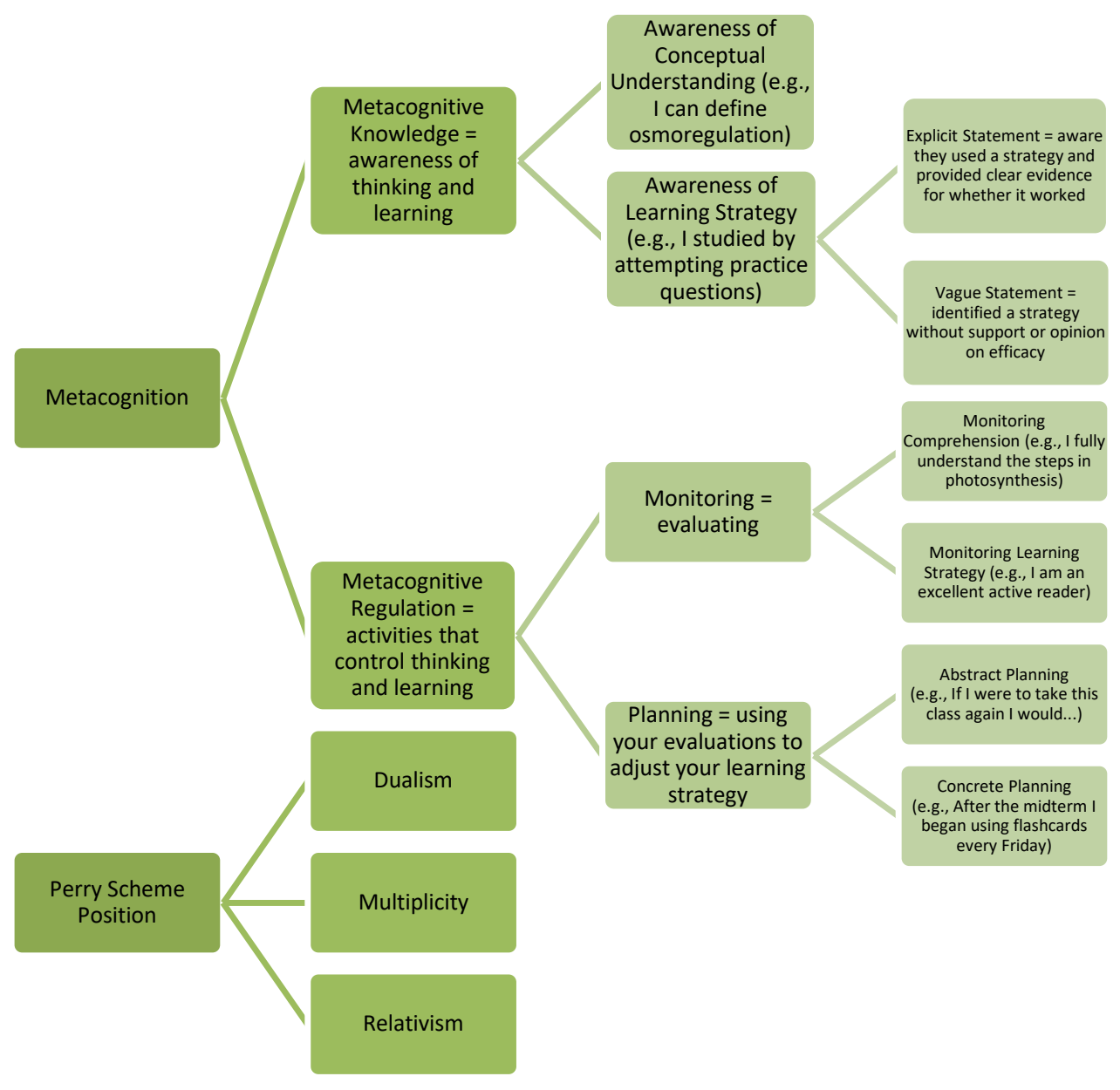

Figure 2

Coding scheme for the qualitative analysis of students' learning philosophy assignments. 


\section{Results}

The LP assignment did not affect the outcome of first-year BSc students' final exam mark relative to their midterm exam in the first-year biology course (Figure 3). However, the second-year biochemistry

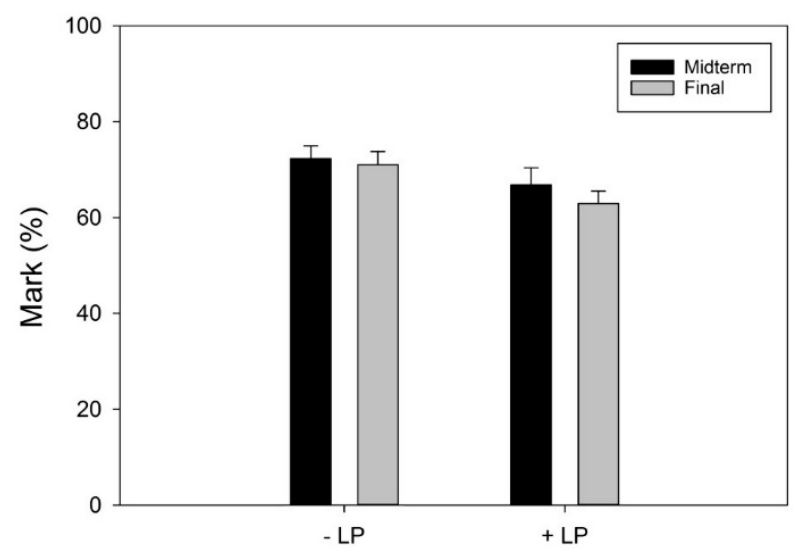

Figure 3

Exam marks of Bachelor of Science students enrolled in a first-year biology course. ${ }^{1}$

students who did not complete the LP assignment experienced a significant decrease in their ability to achieve learning outcomes. This decrease did not occur in the second-year biochemistry students who completed the LP assignment (Figure 4). Additionally, BSc students in first-year biology who completed the LP assignment were rescued from a decrease in cognitive complexity (a measure of intellectual development) that was observed in

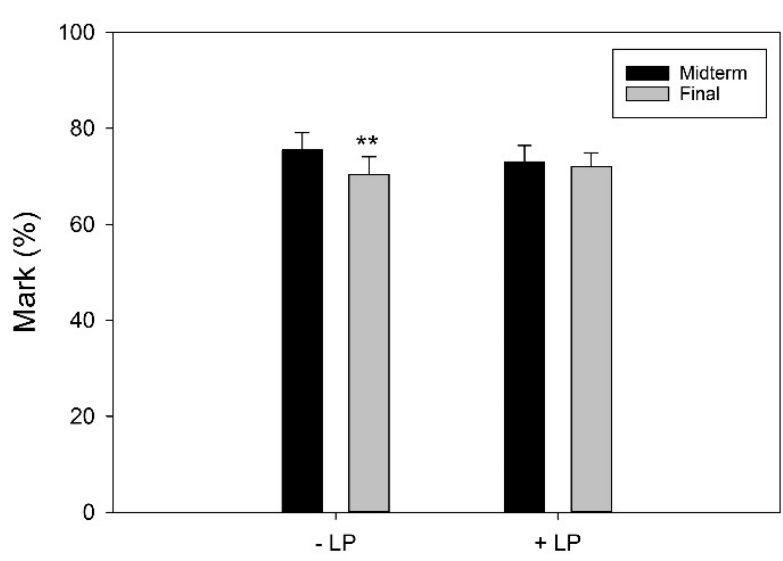

Figure 4

Midterm and final exam marks of second-year biochemistry students. ${ }^{2}$

students who did not complete the assignment (Figure 5). Furthermore, the LP assignment promoted an increase in cognitive complexity in second-year biochemistry students that did not occur in the students that did not complete the assignment (Figure 6).

The content analysis of the first-year and second-year LPs confirmed that our assignment successfully stimulated students' metacognition: all the students engaged in some level of metacognition (Table 3). Regardless of year-level, almost all students exhibited metacognitive knowledge. However, the distribution between recognizing conceptual understanding and recognizing a learning strategy was substantially different. First-year students were far more likely to identify what biological concepts they learnt during the semester $(81 \%)$, while only a

\footnotetext{
${ }^{1}$ In this pre-test/post-test design, students' learning outcomes (exam marks) were considered before and after the learning philosophy (LP) assignment intervention. In the control condition (-LP), changes in learning outcomes are considered without any intervention. Paired one-tailed t-tests within each condition did not detect significant differences between the midterm and final exam scores (\% mark) regardless of whether students completed (+LP; $N=21$ ) or did not complete $(-L P ; N=29)$ a learning philosophy assignment.

${ }^{2}$ In this pre-test/post-test design, students' learning outcomes (exam marks) were considered before and after the learning philosophy (LP) assignment intervention. In the control condition (-LP), changes in learning outcomes are considered without any intervention. Paired one-tailed t-tests detected a significant difference $(* * p=0.00446)$ between the midterm and final exam scores (\% mark) of students who did not complete the learning philosophy assignment (-LP; $N=19)$. There were no significant differences between the midterm and final exam scores (\% mark) of students who did complete the learning philosophy assignment (+LP; $N=24)$.
} 


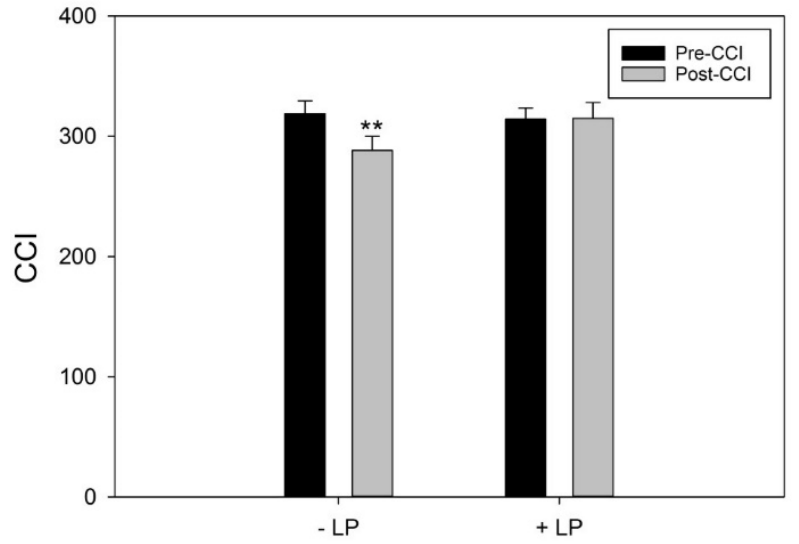

Figure 5

The cognitive complexity index (CCI) of Bachelor of Science students enrolled in a first-year biology course. ${ }^{3}$

single second-year student mentioned specific course content.

I learned in [first-year biology] about the components of the cell, how cells receive energy through different processes such as the Krebs cycle, glycolysis, and photosynthesis. -4241

In contrast, most second-year students (87\%) recognized a learning strategy and their statements were more explicit than those of first-year students. Approximately $74 \%$ of the second-year students made an explicit statement that recognized a learning strategy, compared with approximately $48 \%$ of firstyear students.

In times of lethargy, I would much rather prefer to watch some videos that way I stay focussed because I am

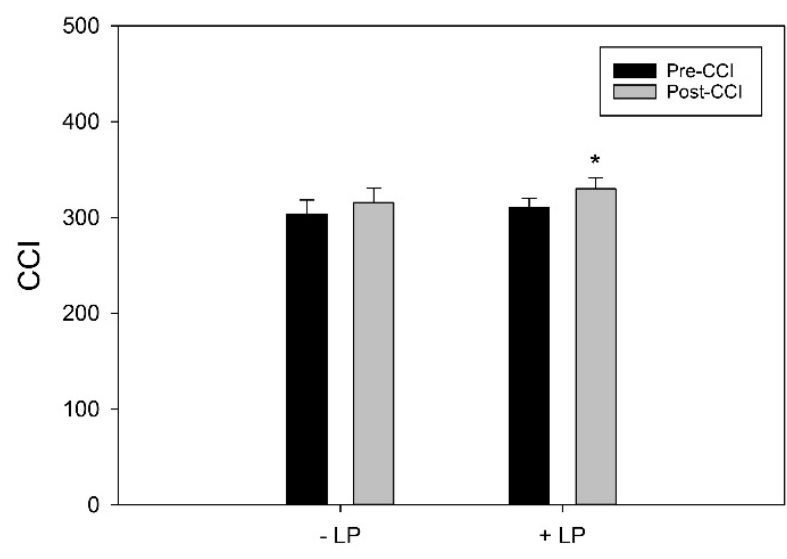

Figure 6

The cognitive complexity index (CCl) of students enrolled in a second-year biochemistry course. ${ }^{4}$

involving more senses such as visual, auditory, taste, and smell. Yes, I do snack while I am learning information through a video, in fact, it makes me feel like I'm not even studying. - Kelsey Sibanda

Metacognitive regulation occurred in all first-year students and $96 \%$ of second-year students. Furthermore, it was coded as either monitoring or planning. Most students in both classes showed evidence of monitoring, however, slightly more second-year students monitored their comprehension.

I did ok, though not great [on the midterm exam], and honestly better than I expected considering my investiture of time and resources. I knew going in that I had no business being there, my command of the material superficial at best, but I could afford no more than what I had already given. - Brandon Wittmeier

\footnotetext{
${ }^{3}$ In this pre-test/post-test design, students' level of intellectual development (CCI) was considered before and after the learning philosophy (LP) assignment intervention. In the control condition (-LP), changes in intellectual development were considered without any intervention. Paired one-tailed t-tests detected a significant difference $(* * p=0.000997)$ between the pre-CCl and post- $\mathrm{CCl}$ of students that did not complete the learning philosophy assignment (-LP; $N=29)$. There were no significant differences in the intellectual development of students who did complete the learning philosophy assignment $(+L P ; N=21)$.

${ }^{4}$ In this pre-test/post-test design, students' level of intellectual development (CCI) was considered before and after the learning philosophy (LP) assignment intervention. In the control condition (-LP), changes in intellectual development were considered without any intervention. Paired one-tailed t-tests detected a significant difference $\left({ }^{*} p=0.0236\right)$ between the start of the course (pre-CCl) and during the last week of classes (post-CCl) of students who completed the learning philosophy assignment $(+L P ; N=24)$. There were no significant differences in the intellectual development of students who did not complete the learning philosophy assignment (-LP; $N=19)$.
} 
All students seemed equally capable of monitoring their learning strategies and most students did so.

I think this course has definitely improved my critical thinking skills and it's helped [me] develop a better way of learning new material. - Natasha Ahmed

Students in both classes were capable of metacognitive planning, however, there were substantial differences in how students planned by year level. Approximately $74 \%$ of second-year students showed evidence of having made or implemented concrete changes to their learning strategies throughout the semester.
In light of my midterm, I have added slight changes to my learning habits. To further my understanding of topics, I have added doing textbook questions to the end of my studying sequence; paying particularly close attention to the ones that require deeper insight. -3017

In contrast, first-year students were more likely $(62 \%)$ to make abstract plans.

I feel like if I was earning this again, I should probably open the text book. -3246

Table 3

Qualitative analysis of metacognition for learning philosophy assignments

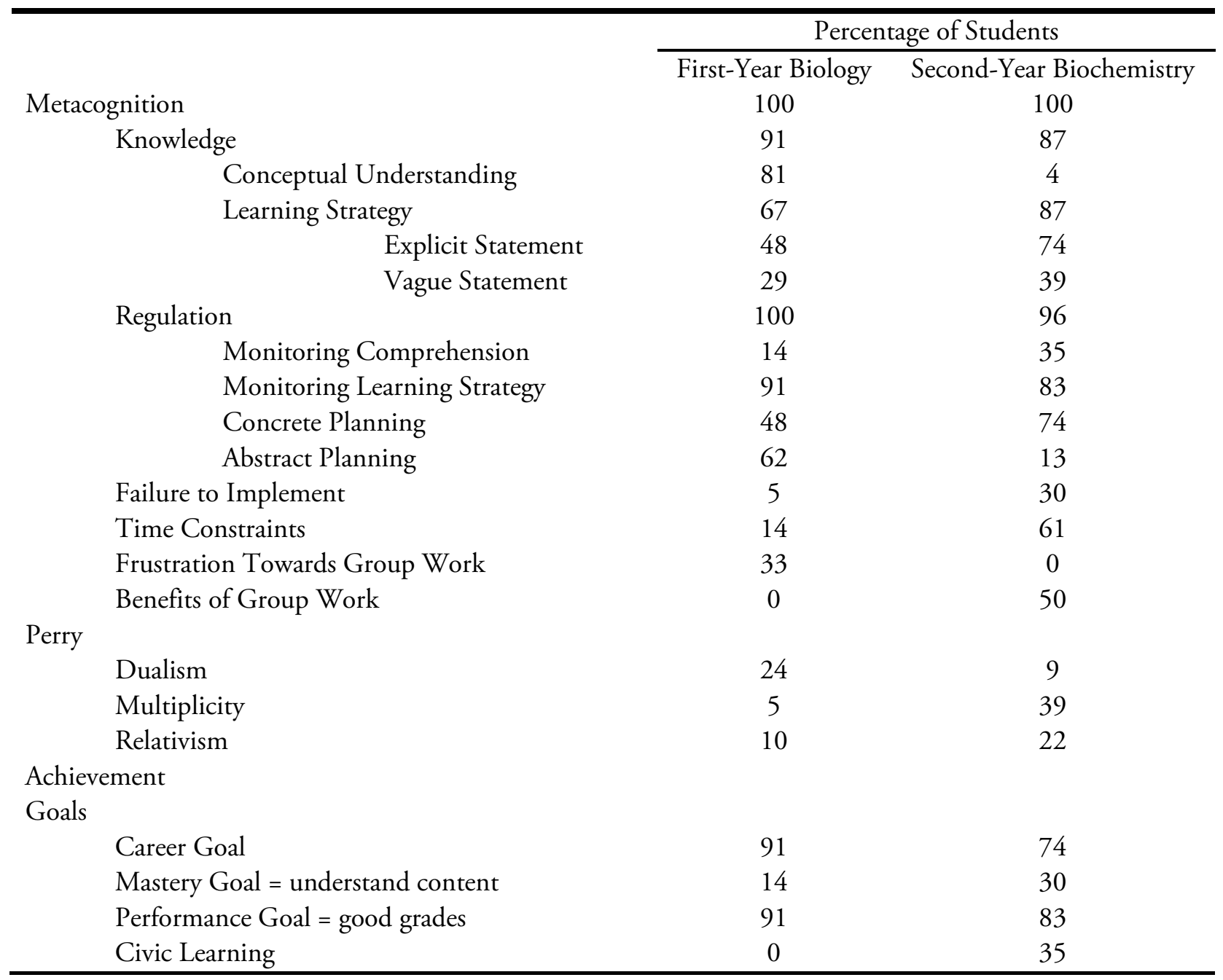


Several other metacognitive patterns emerged during analysis. First, the second-year students were more likely to admit when they failed to implement a planned strategy (30\%).

I had been doing really bad on the quizzes and after putting effort to understand the material I observed a dramatic increase in the marks that I was getting compared to before. The only downfall to this strategy was my personal procrastination. There were days that I wasn't able to keep up and this negatively affected me. I sometimes was not able to go to class prepared enough for the lecture and I would decide not to show up to class. This affected me when it came to the [quiz] and [application] questions in class because some of these question might have been discussed in class. And because I was not there in class, I was not able to fully understand the question. -9899

Next, the second-year students were far more aware of the influence of time constraints when monitoring their learning strategies. Over half of these students (61\%) directly connected time constraints to their failure to properly implement learning strategies or reach achievement goals.

I was able to read more throughout the semester in my studying but with my other courses and the quizzes I never did implement more active studying until the last week ... when my papers were done. - Alexander Olson

Finally, the first-year students expressed substantial negative affect regarding group work, independent learning, and the novelty of the university setting, primarily claiming frustration and drops in confidence.

At the beginning of the course I was very unsure in my abilities, I was not as confident when answering questions and not as involved in the conversation. Doing so much group work at the beginning seemed absurd, but through the course I have definitely grown to appreciate the group and become more comfortable with them. 9314

In contrast, the second-year students were keenly aware of the benefits that group work offered, such that, half of the statements regarding learning strategies were specifically about some form of group work or peer discussion.

Going through these objectives with peers helps me to apply and explain what we have learned. I know this is my most effective learning strategy because if you are able to teach what you have learned, you know it well enough to explain the concepts simply. -5422

The LP assignments were also coded for evidence of the first three stages in the Perry scheme: dualism, multiplicity, and relativism. Approximately $24 \%$ of first year students displayed dualism in their LPs.

However, I still believe that I would have done so much better if I learned the material through my professor's teachings. - Jessa Gualter

Approximately 39\% of second-year students showed evidence of multiplicity in their LPs.

Collaboration is especially important, as it allows an individual to broaden their perspective as they are introduced and challenged by various ideas and opinions. - Carly Rivard

Additionally, approximately $22 \%$ of second-year students showed evidence of relativism.

I always try and justify to my team (and to myself) why I chose an answer. - 5939 
One final theme emerged from our analysis: students exhibited several achievement goals and often more than one. Performance and career goals were the dominant motivation regardless of class. However, second-year students were unique in claiming civic learning goals.

My ultimate goal in life is to be the best contribution to society that I can be whether that be through personal interactions, career achievements, or other avenues. 5529

\section{Discussion}

As an educational theory, constructivism requires an actively engaged learner - to learn deeply, students must cognitively act to construct their mental models of the world (Hartle et al., 2012; Weimer, 2013). Encouraging students to reorganize their mental models entails leading them to consider why their pre-existing knowledge structure might no longer be sufficient (Hartle et al., 2012). However, once identified, alleviating this cognitive dissonance requires metacognitive thought. Only when students become aware of what they think they know can they have any hope of changing it. Metacognition, then, is a necessary component of a constructivist learning environment. The implication is that metacognition has the potential to improve both discipline specific and general learning outcomes. However, not all students have grasped metacognitive thinking and several researchers suggest that metacognition is a skill that institutions should be teaching their students regardless of discipline (Dye \& Stanton, 2017; Girash, 2014; Hartle et al., 2012; Stanton et al., 2015).

The current study attempted to prompt metacognition in first- and second-year biology students using an LP assignment. We then considered whether metacognitive thinking improved specific learning outcomes (course exam marks) and/or general learning outcomes (intellectual development). We found the LP assignment resulted in students' metacognition of their learning, rescued first-year BSc students from a regression in their intellectual development, rescued second-year students from a relatively poorer final exam mark, and promoted the intellectual development of second-year students. Though not identical in format, both courses were assessed with similar exams. The first-year course had a midterm and final exam that consisted of four parts (multiple choice questions, fill-in-the-blank, short answer, and labelling diagrams) whereas the secondyear course was assessed with exams that consisted of a section of multiple choice questions and a section of problems. The inclusion of more problems in the second-year course may have contributed to the observed differences in how first-year and second-year students responded to the LP assignment. Problems were included in the short answer portion of the firstyear course, but these were fewer in number and much less demanding than what was found on the second-year exams. It remains a question to be answered whether the demands of higher order cognitive questions impact how students metacognitively respond to the construction of their learning philosophy. Additionally, because students were not randomly assigned to complete the LP assignment, we cannot remove the possibility of selection bias despite the fact that the +/- LP cohorts were demographically similar.

The effects of the LP assignment were likely caused by guiding students' metacognition, promoting their reflection and adjustments to learning strategies, and promoting reflection on holistic learning (Ash \& Clayton, 2009; Chen, Chavez, Ong, \& Gunderson, 2017; Mynlieff et al., 2014; Stanton et al., 2015). Our qualitative analysis of the LP assignments confirms that the questions were capable of leading students to metacognitive 
thought: all participants, regardless of year, showed some level of metacognition. However, second-year students showed a more advanced level of metacognition. For example, the second-year students were more likely to be cognitively aware of their learning strategies, while first-year students were very focused on conceptual understanding. In addition, second-year students could exceed certain prompts while first-year students remained bound by the question. This was particularly apparent when students were asked to consider how they would relearn the course material. First-year students made abstract plans that remained hypothetical scenarios. However, second-year students made concrete plans and changed their learning strategies between the midterm and final exam. These concrete plans may explain why second-year students were far more aware of failures in their strategic planning - you cannot fail to enact behaviour unless you had a plan to behave in the first place. A willingness to make changes with a failure to enact the change has been previously reported (Dye \& Stanton, 2017; Sebesta \& Bray Speth, 2017; Stanton et al., 2015).

Most institutions are aware that the first semester of first-year can be overwhelming for students (Sebesta \& Bray Speth, 2017). The LP assignments captured the adjustments that students make to the university setting. First-year students expressed substantial frustration and confidence issues regarding independent learning and group work. In contrast, second-year students expressed no negative affect and instead felt group work was a highly effective learning strategy. Recent research into when, why, and how senior undergraduate biology students engage in metacognitive regulation found that the motivation to engage in evaluation is often context dependent - specifically college dependent (Dye \& Stanton, 2017). For example, Dye and Stanton (2017) found many students did not feel the need to evaluate their strategies in high school and were only motivated in a college setting when factors like poor performance, novel challenges, increased information load, and a need for higher-order thinking spurred them into considering new approaches.

While our LP assignment is not sufficient to adequately capture students' positions on the Perry scheme, we did notice a trend in students' LP assignments for first-year students to be more dualistic in their thinking whereas second-year students have a better understanding that there are multiple ways of knowing with a continuum between weak and strong answers similar to what was originally reported by Perry and corroborated by others (Perry, 1998; Wise, Lee, Litzinger, Marra, \& Palmer, 2004).

Our findings correspond to several others that found metacognitive prompts to be effective in enhancing learning outcomes (Mynlieff et al., 2014; Stanton et al., 2015; Zhao et al., 2014). Similarly, improved exam and course scores have been reported when students have been directed to reflect on how to use available course resources (Chen et al., 2017).

During the Augustana e-portfolio pilot students considered what, why, and how they learned while they reflected on the artefacts collected in their e-portfolio. Each of these questions metacognitively engaged students in their learning through the development of their own learning philosophy (Haave, 2014), enabling students to make connections among their different learning experiences in addition to their own personal lives. In one course that was part of the pilot study, students who completed an e-portfolio were rescued from a poor final exam result (Haave, 2016) similar to what we observed in the present study. Typically, students perform more poorly on their final relative to their midterm exam (Zhao et al., 2014).

The CCI scores tend to remain below 400 which approximates Perry position 4: Multiplicity 
(Moore, 1989). Science students tend to score lower on the Perry scheme perhaps because science courses lend themselves to more absolute thinking: there is a correct answer (Finster, 1989). As science students progress in their degree program they should gain experience in understanding the context of experimental design but becoming committed in their chosen profession as a scientist and its accompanying understanding of narrow expertise (commitment in relativism) may not occur until completion of their professional training (Perry, 1998).

Other studies found that encouraging students to consider how they study and to assess whether or not that study approach is working, can improve learning outcomes (Chen et al., 2017; Mynlieff et al., 2014; Stanton et al., 2015; Zhao et al., 2014). However, unlike our study, not all studies assessed the relative academic preparedness of the different cohorts of students. This needs to be considered to ensure that the benefits of engaging students in metacognition of their learning are not simply the result of the control cohort of students being academically weaker than the cohort with the metacognitive intervention.

When students did not participate in the LP intervention in the first-year biology course, their level of intellectual development regressed (their CCI was lower at the end of the term relative to the beginning of term). This suggests that their first term experience of their first year of university is not promoting their intellectual development in the absence of a metacognitive prompt. In contrast, students who completed the LP assignment did not have a decrease in their CCI. This first-year biology course was taught using Team-Based Learning (Michaelsen \& Sweet, 2011). Thus, even an active learning class did not prevent a decrease in CCI. However, this course is only one of typically five courses that the first-year students are experiencing. This result raises the issue of what students' learning experience is really doing for them in the first term of their first year of university. Anecdotally, some students have suggested that they are so busy managing their transition to university from high school, that they really are not cognizant of their intellectual experience, suggesting that the learning philosophy assignment may produce the metacognitive room necessary for them to reflect on the experience. To paraphrase John Dewey, we do not learn from experience... we learn from reflecting on experience (Lagueux, 2014).

Similar to our LP assignment, other studies have shown that writing assignments with metacognitive prompts are able to promote learning outcomes (Linton, Pangle, Wyatt, Powell, \& Sherwood, 2014; Mynlieff et al., 2014; Zhao et al., 2014). The positive impact of metacognitive writing prompts, however, appears to decrease as students gain expertise (Nuckles, Hubner, Dumer, \& Renkl, 2010). We plan to investigate this possibility of an expertise reversal effect as the students in the present study are followed into more senior courses. We are following up on these results to determine if the effects of a learning philosophy assignment persist after the particular course has been completed. Longterm benefits of using metacognitive prompts during students' learning have been shown for primary and secondary (Adey \& Shayer, 1993) but not for postsecondary students.

\section{References}

Adey, P., \& Shayer, M. (1993). An exploration of long-term far transfer effects following an extended intervention program in the high school science curriculum. Cognition and Instruction, 11(1), 1-29. Retrieved from http://www.jstor.org/stable/3233671 
Ambrose, S. A., Bridges, M. W., DiPietro, M., Lovett, M. C., Norman, M. K., \& Mayer, R. E. (2010). How learning works: Seven research-based principles for smart teaching (1st ed.). San Francisco, CA: Jossey-Bass.

Ash, S. L., \& Clayton, P. H. (2009). Documenting learning: The power of critical reflection in applied learning. Journal of Applied Learning in Higher Education, 1, 25-48.

Baxter Magolda, M. B. (2006). Intellectual development in the college years. Change: The Magazine of Higher Learning, 38(3), 5054. https://doi.org/10.3200/CHNG.38. $3.50-54$

Bell, P., \& Volckmann, D. (2011). Knowledge surveys in general chemistry: Confidence, overconfidence, and performance. Journal of Chemical Education, 88(11), 1469-1476. https://doi.org/10.1021/ed100328c

Brady, M., Seli, H., \& Rosenthal, J. (2013). "Clickers" and metacognition: A quasiexperimental comparative study about metacognitive self-regulation and use of electronic feedback devices. Computers \& Education, 65(July), 56-63. https://doi.org/ 10.1016/j.compedu.2013.02.001

Brown, P. C., Roediger III, H. L., \& McDaniel, M. A. (2014). Make it stick. In Make it stick: The science of successful learning (pp. 200-253). Cambridge, MA: The Belknap Press of Harvard University Press.

Chen, P., Chavez, O., Ong, D. C., \& Gunderson, B. (2017). Strategic resource use for learning: A self-administered intervention that guides self-reflection on effective resource use enhances academic performance. Psychological Science, 28(6), 774-785. https://doi.org/10.1177/095679761769645 6

Coutinho, S. A. (2007). The relationship between goals, metacognition, and academic success. Educate-, 7(1), 39-47. Retrieved from http://educatejournal.org/index.php/educat e/article/view/116

Dolan, E. L. (2015). Biology education research 2.0. CBE-Life Sciences Education, 14(4), 1-2. https://doi.org/10.1187/cbe.15-11-0229

Dunning, D., Johnson, K., Ehrlinger, J., \& Kruger, J. (2003). Why people fail to recognize their own incompetence. Current Directions in Psychological Science, 12(3), 83-87. https://doi.org/10.1111/1467-8721.01235

Dye, K. M., \& Stanton, J. D. (2017). Metacognition in upper-division biology students: Awareness does not always lead to control. CBE-Life Sciences Education, 16(2), 1-14. https://doi.org/10.1187/cbe.16-09-0286

Felder, R. M., \& Brent, R. (2004). The intellectual development of science and engineering students. Part 1: Models and challenges. Journal of Engineering Education, 93(4), 269277. https://doi.org/10.1002/j.21689830. 2004.tb00816.x

Finster, D. C. (1989). Developmental instruction: Part I. Perry's model of intellectual development. Journal of Chemical Education, 66(8), 659-661. https://doi.org/10.1021/ed 066p659 
Flavell, J. H. (1979). Metacognition and cognitive monitoring: A new area of cognitive developmental inquiry. American Psychologist, 34(10), 906-911. https://doi. org/10.1037/0003-066x.34.10.906

Freeman, S., Eddy, S. L., McDonough, M., Smith, M. K., Okoroafor, N., Jordt, H., \& Wenderoth, M. P. (2014). Active learning increases student performance in science, engineering, and mathematics. Proceedings of the National Academy of Sciences of the United States of America, 111(23), 8410-5. https://doi.org/10.1073/pnas.1319030111

Girash, J. (2014). Metacognition and instruction. In V. A. Benassi, C. E. Overson, \& C. M. Hakala (Eds.), Applying science of learning in education: Infusing psychological science into the curriculum (pp. 152-168). Society for the Teaching of Psychology. Retrieved from http://teachpsych.org/ebooks/asle2014/inde x.php

Haave, N. (2014). Developing students' learning philosophies. The Teaching Professor, 28(4), 1,4. Retrieved from http://www.facultyfocus .com/articles/teaching-and-learning/develop ing-students-learning-philosophies/

Haave, N. (2016). E-portfolios rescue biology students from a poorer final exam result: Promoting student metacognition. Bioscene: Journal of College Biology Teaching, 42(1), 815. Retrieved from https://eric.ed.gov/?id= EJ1103781

Händel, M., \& Fritzsche, E. S. (2015). Unskilled but subjectively aware: Metacognitive monitoring ability and respective awareness in low-performing students. Memory \& Cognition, 44(2), 229-241. https://doi.org/ $10.3758 / \mathrm{s} 13421-015-0552-0$

Hartle, R. T., Baviskar, S., \& Smith, R. (2012). A field guide to constructivism in the college science classroom: Four essential criteria and a guide to their usage. Bioscene: Journal of College Biology Teaching, 38(2), 31-34. Retrieved from https://eric.ed.gov/?id=EJ10 02158

Hong, W. H., Vadivelu, J., Daniel, E. G. S., \& Sim, J. H. (2015). Thinking about thinking: changes in first-year medical students' metacognition and its relation to performance. Medical Education Online, 20(April 2017), 27561. https://doi.org/10.3 402/meo.v20.27561

Lagueux, R. C. (2014). A spurious John Dewey quotation on reflection. Boston, MA. Retrieved from https://www.academia.edu/1 7358587/A_Spurious_John_Dewey_Quota tion_on_Reflection

Learner-Centered Principles Work Group. (1997). Learner-centered psychological principles: $A$ framework for school reform \& redesign. Washington, DC. Retrieved from https:// www.apa.org/ed/governance/bea/learnercentered.pdf

Linton, D. L., Pangle, W. M., Wyatt, K. H., Powell, K. N., \& Sherwood, R. E. (2014). Identifying key features of effective active learning: The effects of writing and peer discussion. CBE-Life Sciences Education, 13(3), 469-477. https://doi.org/10.1187/cb e.13-12-0242 
Magno, C. (2010). The role of metacognitive skills in developing critical thinking. Metacognition and Learning, 5(2), 137-156. https://doi.org /10.1007/s11409-010-9054-4

Marra, R. M., Palmer, B., \& Litzinger, T. A. (2000). The effects of a first-year engineering design course on student intellectual development as measured by the Perry scheme. Journal of Engineering Education, 89(1), 39-45. https://doi.org/10.1002/j.2168-9830.2000.t b00492.x

Marra, R., \& Palmer, B. (2004). Encouraging intellectual growth: Senior college student profiles. Journal of Adult Development, 11(2), 111-122. https://doi.org/10.1023/B:JADE. $0000024544.50818 .1 \mathrm{f}$

Michaelsen, L. K., \& Sweet, M. (2011). Team-based learning. New Directions for Teaching and Learning, 2011(128), 41-51. https://doi.org/ $10.1002 / \mathrm{tl} .467$

Millis, B. J. (2016). Using metacognition to promote learning. IDEA Paper (Vol. 63). Manhattan, KS. Retrieved from http://www.ideaedu.org/ Portals/0/Uploads/Documents/IDEAPapers /IDEAPapers/PaperIDEA_63.pdf

Moore, W. S. (1989). The learning environment preferences: Exploring the construct validity of an objective measure of the Perry scheme of intellectual development. Journal of College Student Development, 30(6), 504514.

Moore, W. S. (2002). Understanding learning in a postmodern world: Reconsidering the Perry scheme of intellectual and ethical development. In B. K. Hofer \& P. R.
Pintrich (Eds.), Personal epistemology: The psychology of beliefs about knowledge and knowing (pp. 17-36). Mahwah, NJ: Lawrence Erlbaum Associates, Inc.

Mynlieff, M., Manogaran, A. L., St. Maurice, M., \& Eddinger, T. J. (2014). Writing assignments with a metacognitive component enhance learning in a large introductory biology course. CBE-Life Sciences Education, 13(2), 311-321. https://doi.org/10.1187/cbe.1305-0097

Nuckles, M., Hubner, S., Dumer, S., \& Renkl, A. (2010). Expertise reversal effects in writingto-learn. Instructional Science: An International Journal of the Learning Sciences, 38(3), 237-258. https://doi.org/10.1007/s1 1251-009-9106-9

Perry, W. G. (1981). Cognitive and ethical growth: The making of meaning. In A. W. Chickering \& Associates (Eds.), The modern American college (pp. 76-116). San Francisco, CA: Jossey-Bass.

Perry, W. G. (1998). Forms of ethical and intellectual development in the college years: A scheme (revised). San Francisco, CA: Jossey-Bass Publishers.

Pintrich, P. R. (2002). The role of metacognitive knowledge in learning, teaching, and assessing. Theory Into Practice, 41(4), 219225. https://doi.org/10.1207/s15430421 tip 4104_3

Sebesta, A. J., \& Bray Speth, E. (2017). How should I study for the exam? Self-regulated learning strategies and achievement in introductory 
biology. CBE-Life Sciences Education, 16(2), ar30. https://doi.org/10.1187/cbe.16-090269

Smith, B. L. (1998). Curricular structures for cumulative learning. In J. N. Gardner, G. Van der Veer, \& Associates (Eds.), The senior year experience: Facilitating integration, reflection, closure, and transition (pp. 81-94). San Francisco, CA: Jossey-Bass Inc., Publishers.

Stanton, J. D., Neider, X. N., Gallegos, I. J., \& Clark, N. C. (2015). Differences in metacognitive regulation in introductory biology students: When prompts are not enough. CBE-Life Sciences Education, 14(2), ar15. https://doi. org/10.1187/cbe.14-08-0135

Tanner, K. D. (2012). Promoting student metacognition. CBE-Life Sciences Education, 11(2), 113-120. https://doi.org/10.1187/cbe .12-03-0033

Warfa, A.-R. M. (2016). Mixed-methods design in biology education research: Approach and uses. CBE-Life Sciences Education, 15(4), rm5. https://doi.org/10.1187/cbe.16-010022

Weimer, M. (2013). Learner-centered teaching: Roots and origins. In Learner-centered teaching: Five key changes to practice ( $2^{\text {nd }} \mathrm{ed}$., pp. 3-27). San Francisco, CA: Jossey-Bass, a Wiley imprint.

Wise, J. C., Lee, S. H., Litzinger, T., Marra, R. M., \& Palmer, B. (2004). A report on a four-year longitudinal study of intellectual development of Engineering undergraduates.
Journal of Adult Development, 11(2), 103110. https://doi.org/10.1023/B:JADE.0000 024543.83578 .59

Zeegers, P. (2004). Student learning in higher education: a path analysis of academic achievement in science. Higher Education Research \& Development, 23(1), 35-56. https://doi.org/10.1080/072943603200016 8487

Zhao, N., Wardeska, J. G., McGuire, S. Y., \& Cook, E. (2014). Metacognition: An effective tool to promote success in college science learning. Journal of College Science Teaching, 43(4), 48-54. Retrieved from http://www. jstor.org/stable/43632012

\section{Acknowledgements}

We are grateful to have received a grant from the University of Alberta's Teaching and Learning Enhancement Fund to make this project possible. We are also indebted to the students who shared their learning philosophies with us.

\section{Biography}

Neil Haave, $\mathrm{PhD}$, is a Professor at the Augustana Campus of the University of Alberta where he has been teaching molecular cell biology and biochemistry since 1990 and served as Chair of Science and Associate Dean. He currently serves as Associate Director of the Centre for Teaching and Learning. Neil is a recipient of a McCalla Professorship and Augustana's Teaching Leadership Award and Teaching Faculty Award for the Support of Information Literacy. He is a past editor of 
Collected Essays on Learning and Teaching, co-chaired the UofA's Festival of Teaching steering committee, and chaired the 2018 Teaching Professor Conference Advisory Board.

Kelly Keus is completing the last year of her BSc at the Augustana Campus of the University of Alberta. Her research interests tend to traverse disciplinary lines. In 2017, Kelly was awarded Augustana's Outstanding Undergraduate Research Award when she combined her psychology major with her interest in children's literature to research portrayals of PTSD in fantasy fiction. She is a past copy-editor of Collected Essays on Learning and Teaching. Kelly believes her ongoing work as a research assistant will stand her in good stead when she completes her masters in library and information sciences.

Tonya Simpson, BSc, is pursuing an MA in Anthropology at the University of Alberta. Under the supervision of Pamela Mayne Correia, she is currently specializing her study in forensic anthropology. Her thesis work will use forensic case data to consider how the lethal trauma patterns and investigative details of homicide victims in Alberta differ by sex and ancestral affiliation. She hopes that this study will inform community-specific violence prevention strategies. Following graduation, Simpson hopes to pursue a career in forensic anthropology and violence prevention programming within Indigenous communities. 


\section{Appendix A}

\section{Instructions for the Learning Philosophy Assignment}

\section{MT Learning Philosophy Assignment}

To be completed and submitted as an MS Word doc by the time of the $1^{\text {st }}$ MT exam.

Note that the final submission at the end of the term will require a reflection on the results of your MT exam in light of your answers to these questions and whether or not you implemented changes in order to prepare for the final exam.

\section{Questions about learning in general}

- What is learning? What does it mean to learn something?

- Is there a difference between learning a science vs learning an art (e.g. literature, history, painting)?

- What is the relationship between learning/studying on your own vs as a group? Are they different, the same, complementary, or unrelated?

\section{Questions specific to preparing for the exam:}

- How did you learn the material for this course?

- What did you learn for the MT exam in this course?

- Why did you spend time learning this material?

- Will what you've just learned in this course be useful to you in the future? Why? How?

- Are you different now after learning this than you were before? How?
- How did learning this make you feel? Why did it make you feel that way?

- If you were going to learn this again, how would you learn it differently or learn it better?

- Did you get any feedback, say from your instructor or a classmate, as you were learning this? Was it helpful? Did you agree with it? Did you act on it?

More general questions about your education:

- Is the only reason you're taking this course is that it's required?

- Why would the university require a course like this?

- Is this (or any course you're taking) helping you become the person you want to be?

- What do you need to be doing now to make yourself the kind of person you want to be when you leave the university?

\section{Final Learning Philosophy Assignment}

To be completed and submitted as a MS Word doc before the last day of classes. This $2^{\text {nd }}$ submission requires a reflection on the results of your MT exam in light of your answers to these questions and whether or not you implemented changes in order to prepare for the final exam. Write this up as a twopage essay. Ensure that your short essay addresses the questions listed below. The two pages are singlespaced, with 1 inch $(2 \mathrm{~cm})$ margins and 12 pt font.

- Why do you learn? Why have you chosen to learn what you are learning?

- How do you learn? What is the basis/evidence which justifies your choice of learning/studying strategies? Reflect on this in light of the changes you made in response to your MT exam result. If you did not make 
changes to your learning strategies, explain why (e.g. you did well on the MT exam and that is evidence that your study regimen works and shouldn't change. Or that you were unable to implement the changes you wanted to make - ensure that you provide a reason.)

- What is learning? What does it mean to you when you say you have learned something?

- Finally, is your learning/education helping you to develop into the person you wish to be? Please explain yourself.

\section{Appendix B}

\section{Learning Environment Preferences Survey}

This survey asks you to describe what you believe to be the most significant issues in your IDEAL LEARNING ENVIRONMENT. Your opinions are important to us as we study how students think about teaching and learning issues. We ask, therefore, that you take this task seriously and give your responses some thought. We appreciate your cooperation in sharing what you find most important in a learning environment.

The survey consists of five sections, each representing a different aspect of learning environments. In each section, you are presented with a list of specific statements about that particular area. Try not to focus on a specific class or classes as you think about these items; focus on their significance in an ideal learning environment for you.

We ask that you do two things for each section of the instrument:
1) Please rate each item of the section (using the 1-4 scale provided below) in terms of its significance or importance to your learning.

2) Review the list and rank the three most important items to you as you think about your ideal learning environment by writing the item numbers on the appropriate spaces at the bottom of the answer sheet.

Please mark your answers on the separate answer sheet provided and be sure to indicate both your ratings of individual items and your ranking of the top 3 items in each section. It is very important that you indicate your top three choices for each question area by writing the ITEM NUMBER in the spaces provided (1st choice, 2 nd choice, 3 rd choice).

\begin{tabular}{|l|l|l|l|}
\hline $\begin{array}{l}\text { Rating } \\
\text { Scale }\end{array}$ & & & \\
\hline 1 & 2 & 3 & 4 \\
\hline $\begin{array}{l}\text { Not at all } \\
\text { significant }\end{array}$ & $\begin{array}{l}\text { Somewhat } \\
\text { significant }\end{array}$ & $\begin{array}{l}\text { Moderately } \\
\text { significant }\end{array}$ & $\begin{array}{l}\text { Very } \\
\text { significant }\end{array}$ \\
\hline
\end{tabular}

Before you begin, you may be asked to provide us with some background information. This information will be used to examine group differences; your name or social security number may be used at some point in the future if a follow-up survey is required. ALL RESPONSES WILL BE KEPT CONFIDENTIAL. Again, thank you very much for sharing with us your ideas about learning. 


\section{DOMAIN ONE:}

\section{COURSE CONTENT/VIEW OF LEARNING}

MY IDEAL LEARNING ENVIRONMENT

WOULD:

1) Emphasize basic facts and definitions.

2) Focus more on having the right answers than on discussing methods or how to solve problems.

3) Insure that I get all the course knowledge from the professor.

4) Provide me with an opportunity to learn methods and solve problems.

5) Allow me a chance to think and reason, applying facts to support my opinions.

6) Emphasize learning simply for the sake of learning or gaining new expertise.

7) Let me decide for myself whether issues discussed in class are right or wrong, based on my own interpretations and ideas.

8) Stress the practical applications of the material.

9) Focus on the socio-psycho, cultural and historical implications and ramifications of the subject matter.

10) Serve primarily as a catalyst for research and learning on my own, integrating the knowledge gained into my thinking.

11) Stress learning and thinking on my own, or being spoonfed learning by the instructor.

12) Provide me with appropriate learning situations for thinking about and seeking personal truths.

13) Emphasize a good positive relationship among the students and between the students and teacher.
DOMAIN TWO:

ROLE OF INSTRUCTOR

IN MY IDEAL LEARNING ENVIRONMENT, THE TEACHER WOULD:

1) Teach me all the facts and information I am supposed to learn.

2) Use up-to-date textbooks and materials and teach from them, not ignore them.

3) Give clear directions and guidance for all course activities and assignments.

4) Have only a minimal role in the class, turning much of the control of course content and class discussions over to the students.

5) Be not just an instructor, but more an explainer, entertainer and friend.

6) Recognize that learning is mutual individual class members contribute fully to the teaching and learning in the class.

7) Provide a model for conceptualizing living and learning rather than solving problems.

8) Utilize his/her expertise to provide me with a critique of my work.

9) Demonstrate a way to think about the subject matter and then help me explore the issues and come to my own conclusions.

10) Offer extensive comments and reactions about my performance in class (papers, exams, etc.).

11) Challenge students to present their own ideas, argue with positions taken, and demand evidence for their beliefs.

12) Put a lot of effort into the class, making it interesting and worthwhile.

13) Present arguments on course issues based on his/her expertise to stimulate active debate among class members. 
DOMAIN THREE:

ROLE OF STUDENT/PEERS

\section{IN MY IDEAL LEARNING ENVIRONMENT,} AS A STUDENT I WOULD:

1) Study and memorize the subject matter - the teacher is there to teach it.

2) Take good notes on what's presented in class and reproduce that information on the tests.

3) Enjoy having my friends in the class, but other than that classmates don't add much to what I would get from a class.

4) Hope to develop my ability to reason and judge based on standards defined by the subject.

5) Prefer to do independent research allowing me to produce my own ideas and arguments.

6) Expect to be challenged to work hard in the class.

7) Prefer that my classmates be concerned with increasing their awareness of themselves to others in relation to the world.

8) Anticipate that my classmates would contribute significantly to the course learning through their own expertise in the content.

9) Want opportunities to think on my own, making connections between the issues discussed in class and other areas I'm studying.

10) Take some leadership, along with my classmates, in deciding how the class will be run.

11) Participate actively with my peers in class discussions and ask as many questions as necessary to fully understand the topic.

12) Expect to take learning seriously and be personally motivated to learn the subject.

13) Want to learn methods and procedures related to the subject--learn how to learn.
DOMAIN FOUR:

CLASSROOM ATMOSPHERE/ACTIVITIES

\section{IN MY IDEAL LEARNING \\ ENVIRONMENT, THE CLASSROOM \\ ATMOSPHERE AND ACTIVITIES \\ WOULD:}

1) Be organized and well-structured - there should be clear expectations set (like a structured syllabus that's followed).

2) Consist of lectures (with a chance to ask questions) because I can get all the facts I need to know more efficiently that way.

3) Include specific, detailed instructions for all activities and assignments.

4) Focus on step-by-step procedures so that if you did the procedure correctly each time, your answer would be correct.

5) Provide opportunities for me to pull together connections among various subject areas and then construct an adequate argument.

6) Be only loosely structured, with the students themselves taking most of the responsibility for what structure there is.

7) Include research papers, since they demand that I consult sources and then offer my own interpretation and thinking.

8) Have enough variety in content areas and learning experiences to keep me interested.

9) Be practiced and internalized but be balanced by group experimentation, intuition, comprehension, and imagination.

10) Consist of a seminar format, providing an exchange of ideas so that I can critique my own perspectives on the subject matter.

11) Emphasize discussions of personal answers based on relevant evidence rather than just right and wrong answers. 
12) Be an intellectual dialogue and debate among a small group of peers motivated to learn for the sake of learning.

13) Include lots of projects and assignments with practical, everyday applications.

\section{DOMAIN FIVE:}

EVALUATION PROCEDURES

\section{EVALUATION PROCEDURES IN MY}

\section{IDEAL LEARNING ENVIRONMENT}

WOULD:

1) Include straightforward, not "tricky," tests, covering only what has been taught and nothing else.

2) Be up to the teacher, since s/he knows the material best.

3) Consist of objective-style tests because they have clearcut right or wrong answers.

4) Be based on how much students have improved in the class and on how hard they have worked in class.

5) Provide an opportunity for me to judge my own work along with the teacher and learn from the critique at the same time.

6) Not include grades, since there aren't really any objective standards teachers can use to evaluate students' thinking.

7) Include grading by a prearranged point system (homework, participation, tests, etc.), since I think it seems the most fair.

8) Represent a synthesis of internal and external opportunities for judgement and learning enhancing the quality of the class.

9) Consist of thoughtful criticism of my work by someone with appropriate expertise.

10) Emphasize essay exams, papers, etc. rather than objective-style tests so that I can show how much I've learned.
11) Allow students to demonstrate that they can think on their own and make connections not made in class.

12) Include judgments of the quality of my oral and written work as a way to enhance my learning in the class.

13) Emphasize independent thinking by each student, but include some focus on the quality of one's arguments and evidence. 